\title{
Hubungan pemberian kapsul vitamin A dan pengetahuan caregiver dengan stunting pada anak usia 24-59 bulan
}

\author{
Danya Fatimah ${ }^{1}$, Fransisca Chondro ${ }^{2}$
}

\begin{abstract}
ABSTRAK
\section{LATAR BELAKANG}

Stunting adalah masalah gizi kronik yang sering terjadi pada anak usia 24-59 bulan dan akan berdampak pada pertumbuhan dan perkembangan anak. Hasil Riskesdas 2018, terdapat 30.8\% kejadian stunting di Indonesia. Salah satu faktor risiko stunting adalah vitamin A dan pengetahuan caregiver. Penelitian ini bertujuan untuk mengetahui hubungan pemberian kapsul vitamin A program pemerintah dan pengetahuan caregiver dengan stunting pada anak usia 24-59 bulan di Puskesmas Kecamatan Grogol Kusuma Wijaya tahun 2019.
\end{abstract}

\section{METODE}

Desain Penelitian yang digunakan adalah cross sectional. Sampel pada penelitian ini berjumlah 123 anak yang didapat dengan cara consecutive non random sampling. Penelitian ini dilakukan pada bulan SeptemberOktober 2019. Pengumpulan data dilakukan melalui pengukuran tinggi badan anak dan wawancara kuesioner. Analisis data dilakukan dengan uji Chi-square dan uji Fisher-exact.

\section{HASIL}

Proporsi anak stunting di Puskesmas Kecamatan Grogol Kusuma Wijaya mencapai $22.0 \%$, kelengkapan vitamin A sebesar $92.7 \%$, dan pengetahuan caregiver sebagian besar sedang yaitu 49.6\%. Analisis uji statistik menunjukkan adanya hubungan bermakna antara vitamin A dengan kejadian stunting pada anak usia 24-59 bulan $(\mathrm{p}=0.024)$. Dan menunjukan adanya hubungan bermakna antara pengetahuan caregiver dengan kejadian stunting pada anak usia 24-59 bulan $(\mathrm{p}=0.000)$.

\section{KESIMPULAN}

Pemberian kapsul vitamin A dan pengetahuan caregiver dalam penelitian ini berhubungan dengan terjadinya stunting.

Kata kunci: stunting, vitamin A, pengetahuan caregiver, masalah gizi

\author{
${ }^{1}$ Program Studi Kedokteran, \\ Fakultas Kedokteran Universitas \\ Trisakti, Indonesia \\ ${ }^{2}$ Departemen Fisiologi, Fakultas \\ Kedokteran Universitas Trisakti, \\ Indonesia
}

\section{Korespondensi:}

Fransisca Chondro

Departemen Fisiologi Fakultas

Kedokteran Universitas Trisakti, Indonesia

Jalan Kyai Tapa Kampus B, Grogol, Jakarta Barat 11440

Email:

fransisca_chondro@trisakti.ac.id

J Biomedika Kesehat 2020;3(4):176-

182

DOI: $10.18051 /$ JBiomedKes.2020.

v3.176-182

pISSN: 2621-539X / eISSN: 2621-5470

Artikel akses terbuka (open access) ini didistribusikan di bawah lisensi Creative Commons Attribution 4.0 International (CC-BY 4.0) 


\section{ABSTRACT}

\section{Relationship of vitamin a capsule administration and caregiver knowledge with stunting in children aged 24-59 months}

\section{BACKGROUND}

Stunting is a chronic nutritional problem that often occurs in children around age 24-59 months and will definitely have an impact on the growth and development of children. Riskesdas 2018 shows that there were $30.8 \%$ of stunting incidents in Indonesia. Some of the risk factors for stunting are vitamin A and caregiver knowledge. This study aims to determine the correlation of governmental-program-vitamin A capsule intake and caregiver's knowledge with stunting in children aged 24-59 months in Puskesmas Grogol Kusuma Wijaya in 2019.

\section{METHODS}

This study was conducted in September-October 2019 by using cross sectional method on 123 children as respondents which were obtained by using consecutive non random sampling. Data were collected by measuring children's height and questionnaire interview. The collected data then were analyzed using Chi-square test and the Fisher-exact test.

\section{RESULTS}

This study shows the proportion of stunting children in Puskesmas Grogol Kusuma Wijaya was about 22.0\%, completeness of vitamin A by $92.7 \%$, and caregiver knowledge level was mostly medium at $49.6 \%$. The result of the statistic analysis test shows a significant relation between vitamin A intake and stunting incidence in children age 24-59 month $(\mathrm{p}=0.024)$ and also shows a significant relation between caregiver's knowledge and stunting incidence in children age 24-59 month $(\mathrm{p}=0.000)$.

\section{CONCLUSION}

In this study, governmental-program-vitamin A capsule intake and caregiver knowledge are related to the occurrence of stunting.

Keywords: stunting, vitamin A, caregiver knowledge, nutritional problems

\section{PENDAHULUAN}

Masalah perawakan pendek atau yang sering disebut stunting merupakan masalah terbanyak di dunia khususnya di negara berkembang, salah satunya adalah Indonesia. (1) Menurut World Health Organization (WHO) 2017, Indonesia merupakan peringkat ketiga negara dengan prevalensi stunting tertinggi di Asia Tenggara. Prevalensi stunting di Indonesia pada tahun 2015-2017 mencapai angka 36.4\%. Stunting adalah keadaan di mana balita memiliki panjang atau tinggi badan kurang jika di bandingkan dengan anak seusianya, di ukur melalui panjang atau tinggi badan dengan hasil <-2 standar deviasi di bawah median standar pertumbuhan anak menurut WHO. ${ }^{(2)}$ Menurut data Riset Kesehatan Dasar (Riskesdas) 2018 prevalensi stunting pada balita mencapai angka $30.8 \%$. $^{(3)}$

Fase balita terjadi pertumbuhan dan perkembangan yang sangat pesat, disamping itu balita juga biasanya memiliki gangguan nafsu makan, serta mendapat asupan zat gizi yang tidak sesuai kuantitas atau kualitasnya sehingga menyebabkan masalah gizi. ${ }^{(4)} \mathrm{Hal}$ ini disebabkan karena kurangnya pengetahuan dan penanganan gizi orang tua. ${ }^{(5)}$ Stunting termasuk kedalam permasalahan status gizi kronik. ${ }^{(2,6)}$ Masalah ini juga dapat menyebabkan perkembangan dan pertumbuhan terganggu terutama dalam 1000 hari pertama kehidupan $(\mathrm{HPK}){ }^{(7)}$ dan dapat menyebabkan anak mudah terkena infeksi, menyebabkan resiko penyakit terutama penyakit tidak menular seperti hipertensi, diabetes, kanker dan obesitas. ${ }^{(2,8)}$ Menurut Riskesdas 2018 prevalensi gizi kurang dan gizi buruk di Indonesia pada anak di bawah usia lima tahun mencapai angka $17.7 \%$. $^{(3)}$

Banyak faktor yang mempengaruhi terjadinya stunting diantaranya, faktor ekonomi keluarga, pendidikan, pengetahuan asupan gizi sesuai dengan kebutuhan. Perilaku pemberian makan oleh pengasuh mencakup keputusan mengenai bagaimana, mengapa, kapan, dan apa yang mereka berikan kepada anak-anak. Penelitian yang dilakukan sebelumnya mendapatkan hasil ibu balita stunting $(61.8 \%)$ memiliki pengetahuan gizi yang lebih rendah daripada ibu balita normal $(29.4 \%)^{(6)}$. Hal ini menunjukkan betapa pentingnya pengetahuan berkaitan dengan upaya pencegahan stunting.

Menurut Riskedas tahun 2018 di Indonesia pemberian kapsul vitamin A yang tidak sesuai standar mencapai angka 28.8\% dan yang tidak pernah mendapatkan kapsul vitamin 
A mencapai angka $17.6 \% .{ }^{(2)}$ Pada penelitian sebelumnya menunjukkan bahwa $>60 \%$ anak masih mengalami defisiensi vitamin A, yaitu kadar vitamin A serum $<20 \mu \mathrm{g} / \mathrm{dl}$ meskipun sudah mendapatkan suplementasi vitamin A dosis tinggi. ${ }^{(9)}$ Anak yang kekurangan vitamin A akan memiliki risiko yang lebih tinggi untuk terjadinya kegagalan dalam pertumbuhan dan juga penurunan respon imunitas, sehingga rentan untuk terkena infeksi. $(10,11)$

Banyak penelitian terdahulu yang telah meneliti kaitan antara asupan vitamin A dan kejadian stunting. Dikarenakan banyaknya ibu bekerja dan anak diasuh oleh caregiver lain (selain ibu), maka dalam penelitian ini peneliti bermaksud untuk menilai hubungan vitamin A dan pengetahuan caregiver dengan stunting pada anak usia 24-59 bulan. Pada penelitian ini, yang dinilai bukan hanya pengetahuan ibu, tetapi pengetahuan caregiver yang mengasuh anak secara langsung, baik ibu maupun orang lain yang ditugaskan.

\section{METODE}

Penelitian ini dilaksanakan di Puskesmas Kecamatan Grogol Petamburan Wijaya Kusuma, pada bulan September-Oktober 2019. Penelitian ini termasuk dalam lingkup penelitian analitik observasional dengan menggunakan pendekatan cross-sectional. Populasi dalam penelitian ini adalah caregiver dari anak usia 24-59 bulan, dengan jumlah subjek 123 orang. Subjek penelitian dipilih secara consecutive non random sampling dengan kriteria inklusi anak usia 24-59 bulan dan caregiver dari anak tersebut yang bersedia menjadi subjek penelitian. Sedangkan kriteria ekslusi adalah anak yang telah di diagnosis gangguan mental dan anak yang tidak memiliki caregiver.

Variabel bebas pada penelitian ini adalah vitamin A dan pengetahuan caregiver, karakteristik sosiodemografi yang meliputi pendidikan caregiver, status ekonomi keluarga, serta usia caregiver. Variabel tergantungnya adalah stunting. Pengambilan data menggunakan alat microtoise untuk mengukur tinggi badan anak, Data kelengkapan vitamin A responden didapatkan dengan cara mewawancari responden ataupun dengan cara melihat kartu menuju sehat dan Kuisioner pengetahuan gizi digunakan untuk mendapat data mengenai pengetahuan caregiver. Analisis data dilakukan dengan analisis univariat dan bivariat menggunakan uji statistik Chi-square dan Fisher-exact.

\section{HASIL}

Hasil analisis univariat pada penelitian ini jumlah sampel yang didapatkan adalah sebanyak 123 responden dan telah memenuhi kriteria inklusi untuk dimasukkan ke dalam penelitian sampai batas waktu yang ditentukan. Deskripsi hasil penelitian menjelaskan mengenai keseluruhan data penelitian yang dikumpulkan yaitu variabel tergantung dan variabel bebas dengan mengklasifikasikan ke dalam tabel.

\section{Tabel 1. Distribusi frekuensi responden}

\begin{tabular}{lcc}
\hline \multicolumn{1}{c}{ Karakteristik } & $\mathbf{n}$ & $\mathbf{\%}$ \\
\hline Usia Caregiver (tahun) & & \\
Remaja Akhir (17-25 tahun) & 16 & 13.0 \\
Dewasa (26 - 55 tahun) & 100 & 81.3 \\
$\quad$ Lansia (> 55 tahun) & 7 & 5.7 \\
Tingkat Pendidikan Caregiver & & 44.7 \\
$\quad$ Rendah (SD - SMP) & 55 & 55.3 \\
$\quad$ Tinggi (SMA - PT) & 68 & \\
Pendapatan & & \\
Dibawah UMR DKI Jakarta & 22 & 44.7 \\
$\quad$ Diatas atau sama dengan & 101 & 55.3 \\
UMR DKI Jakarta & & \\
Vitamin A & 114 & 92.7 \\
$\quad$ Lengkap & 9 & 7,3 \\
Tidak Lengkap & 52 & 42.3 \\
Pengetahuan Caregiver & 61 & 49.6 \\
$\quad$ Tinggi & 10 & 8.1 \\
Sedang & & \\
Rendah & 27 & 22.0 \\
Stunting & 96 & 78.0 \\
$\quad$ Ya & & \\
Tidak/Normal &
\end{tabular}

Berdasarkan Tabel 1 dapat dilihat bahwa dari 123 responden, frekuensi terbanyak adalah Vitamin A Lengkap berjumlah 114 orang (92.7\%) dan diketahui pada pengetahuan caregiver umumnya memiliki tingkat pengetahuan sedang, yakni berjumlah 61 orang (49.6\%). Juga diketahui bahwa masih banyak anak yang mengalami stunting, yakni 27 anak (22.0\%). Hasil analisis bivariat vitamin A dengan stunting dilakukan untuk mengetahui apakah terdapat hubungan kelengkapan pemberian vitamin A dengan kejadian stunting.

Sebagian besar anak yang mendapatkan vitamin A secara berkesinambungan yang sesuai dengan jadwal yang dianjurkan oleh pemerintah tidak mengalami stunting atau memiliki tinggi badan normal dan sebagian anak yang tidak mendapatkan kelengkapan vitamin A, yakni 
Tabel 2. Hubungan pemberian vitamin A dan kejadian stunting

\begin{tabular}{|c|c|c|c|c|c|}
\hline \multirow{3}{*}{ Variabel } & \multicolumn{4}{|c|}{ Stunting } & \multirow{3}{*}{$p$} \\
\hline & \multicolumn{2}{|c|}{ Ya } & \multicolumn{2}{|c|}{ Tidak/Normal } & \\
\hline & $\mathbf{n}$ & $\%$ & $\mathbf{n}$ & $\%$ & \\
\hline \multicolumn{6}{|l|}{ Vitamin A } \\
\hline Lengkap & 21 & 18.75 & 91 & 81.25 & \multirow{2}{*}{$0.024 \ddagger$} \\
\hline Tidak Lengkap & 5 & 55.55 & 4 & 44.44 & \\
\hline
\end{tabular}

+: Uji Fisher

sebanyak 9 anak, 5 diantaranya mengalami stunting. Dari hasil uji Fisher pada Tabel 2 dapat disimpulkan terdapat hubungan yang bermakna antara kelengkapan pemberian vitamin A dengan kejadian stunting dengan $\mathrm{p}=0.024$.

Hasil analisis bivariat pengetahuan caregiver dengan stunting dilakukan untuk mengetahui apakah terdapat hubungan antara pengetahuan caregiver dan kejadian stunting.

Sebagian besar caregiver yang memiliki pengetahuan sedang, mempunyai anak yang mengalami stunting. Hasil uji Chi-square pada Tabel 3 menunjukkan terdapat hubungan antara pengetahuan caregiver dengan kejadian stunting pada penelitian ini dengan $\mathrm{p}=0.000$. Hasil analisis bivariat tingkat pendidikan dengan pengetahuan caregiver dilakukan untuk mengetahui terdapat hubungan antara tingkat pendidikan dan pengetahuan caregiver.

Pada penelitian ini, responden juga kami tanyakan tingkat pendidikannya. Responden dengan tingkat Pendidikan SD-SMP dikelompokkan ke dalam pendidikan rendah, sedangkah responden yang memiliki tingkat pendidikan SMU atau lebih tinggi dimasukkan ke dalam kelompok pendidikan tinggi. Sebagian besar caregiver dengan tingkat pendidikan tinggi memiliki tingkat pengetahuan yang tinggi. Hasil uji Chi-square pada Tabel 4 menunjukkan terdapat hubungan yang bermakna antara tingkatpendidikan dan pengetahuan caregiver pada penelitian ini dengan $\mathrm{p}=0.000$. Hasil analisis bivariat pendapatan dengan pengetahuan caregiver dilakukan untuk mengetahui terdapat hubungan antara pendapatan dan pengetahuan caregiver. Pada penelitian ini, pendapatan responden dikelompokkan menjadi 2 yakni di bawah UMR dan sama dengan/di atas UMR. Untuk besaran UMR yang digunakan adalah UMR DKI Jakarta tahun 2019 yakni sebesar Rp. 3.940.937,-. Sebagian besar caregiver yang memiliki pendapatan di atas atau sama dengan UMR memiliki tingkat pengetahuan yang sedang. Hasil uji Chi-square menunjukkan tidak terdapat hubungan yang bermakna antara pendapatan dan pengetahuan caregiver pada penelitian ini $(\mathrm{p}=0.546)$.

Hasil analisis bivariat usia dengan pengetahuan caregiver dilakukan untuk mengetahui terdapat hubungan antara usia caregiver dan pengetahuan caregiver. Pada penelitian ini, berdasarkan usianya, responden dibagi ke dalam 3 kelompok yakni kelompok remaja akhir (17-25 tahun), dewasa (26-55 tahun) dan lansia ( $>55$ tahun). Sebagian besar caregiver yang berusia dewasa memiliki tingkat pengetahuan yang sedang. Hasil uji Chi-square menunjukkan tidak terdapat hubungan yang bermakna antara usia caregiver dan pengetahuan caregiver pada penelitian ini $(\mathrm{p}=0.342)$.

Keterbatasan penelitian pada penelitian ini, peneliti hanya menilai apakah responden menerima suplementasi vitamin A dengan lengkap sesuai jadwal yang telah ditentukan dari program pemerintah, namun tidak melakukan pengukuran asupan vitamin A secara mandiri di luar jadwal tersebut, contohnya pemberian multivitamin dan

Tabel 3. Hubungan pengetahuan caregiver dan kejadian stunting

\begin{tabular}{|c|c|c|c|c|c|}
\hline \multirow{3}{*}{ Variabel } & \multicolumn{4}{|c|}{ Stunting } & \multirow{3}{*}{$p$} \\
\hline & \multicolumn{2}{|c|}{ Ya } & \multicolumn{2}{|c|}{ Tidak/Normal } & \\
\hline & $\mathbf{n}$ & $\%$ & $\mathbf{n}$ & $\%$ & \\
\hline \multicolumn{6}{|l|}{ Pengetahuan } \\
\hline Tinggi & 6 & 11.53 & 46 & 88.46 & \multirow{3}{*}{$0.000^{*}$} \\
\hline Sedang & 13 & 22.03 & 46 & 77.96 & \\
\hline Rendah & 7 & 70.00 & 3 & 30.00 & \\
\hline
\end{tabular}

*: Uji Chi-square 
Tabel 4. Hubungan tingkat pendidikan, pendapatan, usia caregiver dengan pengetahuan caregiver

\begin{tabular}{|c|c|c|c|c|c|c|c|}
\hline \multirow{3}{*}{ Variabel } & \multicolumn{6}{|c|}{ Pengetahuan Caregiver } & \multirow{3}{*}{$p$} \\
\hline & \multicolumn{2}{|c|}{ Tinggi } & \multicolumn{2}{|c|}{ Sedang } & \multicolumn{2}{|c|}{ Rendah } & \\
\hline & $\mathbf{n}$ & $\%$ & n & $\%$ & $n$ & $\%$ & \\
\hline \multicolumn{8}{|l|}{ Tingkat Pendidikan } \\
\hline Rendah & 8 & 14.54 & 37 & 67.27 & 10 & 18.18 & $0.000 *$ \\
\hline Tinggi & 44 & 64.70 & 24 & 35.29 & 0 & 0 & \\
\hline \multicolumn{8}{|l|}{ Pendapatan } \\
\hline Dibawah UMR & 7 & 31.81 & 13 & 59.09 & 2 & 9.09 & $0.546^{*}$ \\
\hline Diatas sama dengan UMR & 45 & 44.55 & 48 & 47.52 & 8 & 7.92 & \\
\hline \multicolumn{8}{|l|}{ Usia caregiver } \\
\hline Remaja Akhir & 6 & 37,5 & 9 & 56,25 & 1 & 6,25 & $0.342 *$ \\
\hline Dewasa & 44 & 44.00 & 49 & 49.00 & 7 & 7.0 & \\
\hline Lansia & 2 & 28.57 & 3 & 42.85 & 2 & 28.57 & \\
\hline
\end{tabular}

*: Uji Chi-square

juga vitamin yang didapatkan anak dari asupan makanan sehari-hari.

\section{PEMBAHASAN}

Terkait dengan kelengkapan vitamin A dengan kejadian stunting diketahui pada penelitian ini menunjukan hubungan yang bermakna antara vitamin A dan stunting. Hasil uji Fisher pada Tabel 2 menunjukkan terdapat hubungan antara kelengkapan pemberian vitamin A dengan kejadian stunting $(\mathrm{p}=0.024)$. Hal ini sejalan dengan penelitian sebelumnya yang menunjukan bahwa terdapat perbedaan yang signifikan antara kelompok stunting dan non stunting pada variabel tingkat kecukupan vitamin $\mathrm{A}(\mathrm{p}=0.002) .{ }^{(12)}$ Pada penelitian yang dilakukan di Karangasem Bali juga menemukan perbedaan yang signifikan tingkat kecukupan vitamin A antara balita stunting dan non stunting. ${ }^{(13)}$ Hasil penelitian lainnya menyatakan bahwa asupan vitamin A merupakan mikronutrien yang berkontribusi dengan kejadian stunting pada anak usia 12-60 bulan. ${ }^{(14)}$ Penelitian lainnya juga menyatakan terdapat hubungan antara suplementasi vitamin A dengan kejadian stunting $(\mathrm{p}=0.000)$. Ia juga menyatakan bahwa anak yang tidak mendapatkan suplementasi vitamin A memiliki resiko 2.40 lebih besar untuk menderita stunting jika dibandingkan dengan yang mendapatkan vitamin $\mathrm{A} .{ }^{(15)}$

Namun terdapat beberapa penelitian lain yang tidak sejalan seperti yang didapatkan hasil yang menunjukan bahwa tidak ada hubungan yang signfikan antara asupan vitamin $\mathrm{A}(\mathrm{p}=0.982)$ dan kejadian stunting. ${ }^{(16)}$ Selain itu juga pada penelitian lainnya didapatkan hasil yang menunjukan tidak adanya hubungan antara tingkat kecukupan vitamin A dengan kejadian stunting $(\mathrm{p}=0.299)$.
Namun, hasil penelitian lainnya menunjukkan bahwa $72.7 \%(\mathrm{n}=56)$ baduta yang kurang taat konsumsi vitamin A mengalami stunting dan angka tersebut lebih besar dibandingkan baduta yang normal. ${ }^{(17)}$ Adanya perbedaan hasil pada penelitian dimungkinkan perbedaan cakupan populasi target serta distribusi data variabel pada tiap masing-masing penelitian.

Pada penelitian ini terkait pengetahuan caregiver dengan kejadian stunting hasil uji Chisquare menunjukan terdapat hubungan yang bermakna antara pengetahuan caregiver dengan kejadian stunting $(\mathrm{p}=0.000)$. Hal ini sejalan dengan penelitian sebelumnya yang menunjukkan bahwa rumah tangga dengan perilaku sadar gizi yang kurang baik berpeluang meningkatkan risiko kejadian stunting pada anak balita 1.22 kali dibandingkan dengan rumah tangga dengan perilaku kesadaran gizi baik. ${ }^{(18)} \mathrm{Hal}$ tersebut sejalan dengan penelitian yang menunjukan adanya hubungan antara pengetahuan gizi ibu dengan stunting pada anak usia 4-5 tahun $(\mathrm{p}=0.015){ }^{(6)}$ Namun, hasil ini tidak sejalan dengan penelitian menunjukan bahwa tidak ada hubungan antara tingkat pengetahuan dengan kejadian stunting $(\mathrm{p}=0.963){ }^{(19)}$

Berkaitan tentang tingkat pendidikan dengan pengatahuan caregiver mengenai stunting, hasil uji Chi-square pada Tabel 4 menunjukan terdapat hubungan antara tingkat pendidikan caregiver dengan pengetahuan caregiver pada penelitian ini $(\mathrm{p}=0.000)$. Hal ini sejalan dengan penelitian yang menyatakan terdapat hubungan yang bermakna antara pendidikan dengan pengetahuan ibu dengan $p=0.01$. Penelitian tersebut mengatakan bahwa pendidikan merupakan salah satu faktoryang berpengaruh terhadap pengetahuan 
seseorang. Semakin tinggi tingkat pendidikannya, maka seseorang akan semakin mudah menerima dan mengaplikasikan pengetahuan tersebut. ${ }^{(20)} \mathrm{A}$. $\mathrm{K}$. Christian mengatakan bahwa pengetahuan ibu yang diperoleh melalui pendidikan informal atau rendah memiliki konsekuensi negative mengenai indikator status gizi pada anak. ${ }^{(21)}$

Berkaitan tentang pendapatan dan pengetahuan caregiver mengenai stunting, hasil uji Chi-square pada Tabel 4 menunjukkan tidak terdapat hubungan antara pendapatan dengan pengetahuan caregiver mengenai stunting pada penelitian ini dengan $(\mathrm{p}=0.546)$. Hal ini berbeda dengan hasil yang didapatkan pada penelitian Castro dkk yang menyatakan terdapat hubungan antara status ekonomi dan pengetahuan tentang dengue. Dikatakan bahwa masyarakat dengan tingkat ekonomi yang lebih baik mengakses lebih banyak informasi melalui televisi, radio, ataupun surat kabar, sehingga dapat memiliki informasi dan pengetahuan yang lebih baik. ${ }^{(22)}$

Berkaitan tentang usia dan pengetahuan caregiver mengenai stunting, hasil uji Chi-square juga menunjukkan tidak terdapat hubungan antara usia dengan pengetahuan caregiver mengenai stunting pada penelitian ini dengan $(\mathrm{p}=0.342)$. Hal ini sejalan dengan penelitian sebelumnya yang menyatakan tidak ada hubungan antara usia dengan pengetahuan ibu $(\mathrm{p}=0.054){ }^{(20)}$

\section{KESIMPULAN}

Dari hasil penelitian dapat disimpulkan bahwa terdapat hubungan yang bermakna antara pemberian kapsul vitamin A program pemerintah dengan kejadian stunting pada anak usia 24-59 bulan. Selain itu, terdapat hubungan yang bermakna antara hubungan pengetahuan caregiver dengan kejadian stunting pada anak usia 24-59 bulan. Dapat disimpulkan bahwa vitamin A dan pengetahuan caregiver merupakan salah satu faktor yang berperan penting dalam pertumbuhan anak.

\section{UCAPAN TERIMA KASIH}

Ibu Oppi selaku staf di Puskesmas Kecamatan Grogol Petamburan Jakarta Barat yang telah membantu, meluangkan waktu, memberi izin dan menyediakan fasilitas sehingga peneliti dapat menjalankan penelitian dan terima kasih juga kepada seluruh responden yang telah berkontribusi.

\section{REFERENSI}

1. Rahmayana, Ibrahim IA, Damayati DS. Hubungan pola asuh ibu dengan kejadian stunting anak usia 24-59 bulan di posyandu asoka II wilayah pesisir kelurahan baromong kecamatan tamalate kota makassar tahun 2014. Public Health Science Journal. 2014;6(2):424-36. doi: 10.24252/ as.v6i2.1965

2. Kementrian Kesehatan RI. Buletin Jendela Data dan Informasi Kesehatan: Situasi Balita Pendek (Stunting) di Indonesia. Jakarta: Kementrian Kesehatan RI; 2018. p.1-17

3. Kementerian Kesehatan RI. Hasil Utama Riskesdas 2018. Jakarta: Kementerian Kesehatan RI; 2018

4. Muharry A, Kumalasari I, Dewi ER. Faktor yang mempengaruhi status gizi balita di Puskesmas Nelayan Kota Cirebon. Jurnal Ilmu Kesehatan. 2017;1(1):25-33. doi: 10.33006/ji-kes.vli1.41

5. Wiyono S. Buku Ajar Epidemiologi Gizi Konsep dan Aplikasi. Jakarta. Sagung Seto; 2016

6. Ni'mah K, Nadhiroh SR. Faktor yang berhubungan dengan kejadian stunting pada balita [Internet]. Media Gizi Indonesia. 2015;10(1):13-9. Available from: https://e-journal.unair.ac.id/MGI/article/ view/3117

7. Kementerian Kesehatan RI. Infodatin Situasi Balita Pendek. Jakarta: Kementerian Kesehatan RI; 2016

8. Mohammed SH, Larijani B, Esmaillzadeh A. Concurrent anemia and stunting in young children: prevalence, dietary and non-dietary associated factors. Nutr J. 2019;18(10):1-10. doi: 10.1186/ s12937-019-0436-4

9. Fedriyansyah, Nazir HM, Theodorus, et al. Hubungan kadar seng dan vitamin A dengan kejadian ISPA dan diare pada anak. Sari Pediatri 2010;12(4):241-6. doi: 10.14238/sp12.4.2010.2416

10. Sandjaja, Sudikno. Serum retinol binding protein (Rbp) ibu menyusui dan bayinya di dua kabupaten di Jawa Barat. Gizi Indonesia. 2015;38(2):143-54. doi: $10.36457 /$ gizindo.v38i2.188

11. Elvandari M, Briawan D, Tanziha I. Suplementasi vitamin A dan asupan zat gizi dengan serum retinol dan morbiditas anak 1-3 tahun. Jurnal Gizi Klinik Indonesia. 2017;13(4):179-87. doi: 10.22146/ ijcn. 17938

12. Kementerian Kesehatan RI. Kondisi Pencapaian Program Kesehatan Anak Indonesia. Jakarta: Pusat Data Informasi Kementrian Kesehatan RI; 2014. p.1-12.

13. Mitra M. Permasalahan anak pendek (stunting) dan intervensi untuk mencegah terjadinya stunting (suatu kajian kepustakaan) [Internet]. Jurnal Kesehatan Komunitas. 2015; 2(6):254-61. Available from: https://jurnal.htp.ac.id/index.php/ keskom/article/view/85

14. Fatimah NSH, Wirjatmadi BR. Tingkat kecukupan vitamin A, seng dan zat besi serta frekuensi infeksi pada balita stunting dan non stunting. Media Gizi Indonesia. 2018; 13( 2):168-75. doi: 10.20473/ mgi.v13i2.168-175

15. Simanjuntak BY, Haya M, Suryani $D$, et al. Early initiation of breastfeeding and vitamin A supplementation with nutritional status of children aged 6-59 months. Kesmas: Jurnal Kesehatan 
Masyarakat Nasional. 2018;12(3):107-13. doi:10.21109/kesmas.v12i3.1747

16. Bahmat DO, Bahar H, Jus'at I. Correlation of zinc, vitamin A and iron intake of toddlers (2459 month) and maternal education with stunting in islands Nusa Tenggara (secondary data analysis of Riskesdas 2010) [Internet]. Jakarta: Universitas Esa Unggul; 2015 Sep. Available from: https://digilib.esaunggul.ac.id/public/UEUUndergraduate-5792-Jurnal.pdf

17. Wellina WF, Kartasurya MI, Rahfilludin MZ. Faktor risiko stunting pada anak umur 12-24 bulan. Jurnal Gizi Indonesia. 2016;5(1):55-61. doi: 10.14710/jgi.5.1.55-61

18. Riyadi H, Martianto D, Hastuti D, et al. Faktorfaktor yang mempengaruhi status gizi anak balita di Kabupaten Timor Tengah Utara, Provinsi Nusa Tenggara Timur. Jurnal Gizi dan Pangan. 2011;6(1):66-73. doi:10.25182/jgp.2011.6.1.66-73

19. Ni'mah C, Muniroh L. Hubungan tingkat pendidikan, tingkat pengetahuan dan pola asuh ibu dengan wasting dan stunting pada balita keluarga miskin. Media Gizi Indonesia. 2015;10(1): 84-90. doi:10.20473/mgi.v10i1.84-90

20. Rahmadiani RD, Astuti S, Susanti AI, et al. Hubungan pengetahuan ibu balita tentang stunting dengan karakteristik ibu dan sumber informasi di desa Hegarmanah Kecamatan Jatinangor Kabupaten Sumedang [Internet]. Jurnal Sistem Kesehatan. 2019;5(2):74-80. Available from: http:// jurnal.unpad.ac.id/jsk_ikm/article/view/25661

21. Christian AK, Marquis GS, Colecraft EK, et al. Caregivers' nutrition knowledge and attitudes are associated with household food diversity and children's animal source food intake across different agro-ecological zones in Ghana. $\mathrm{Br}$ J Nutr. 2016;115(2):351-60. doi: 10.1017/ S0007114515004468

22. Castro M, Sanchez L, Perez D, et al. The relationship between economic status, knowledge on dengue, risk perceptions and practices. PLoS ONE. 2013;8(12):e81875. doi:10.1371/journal. pone. 0081875 